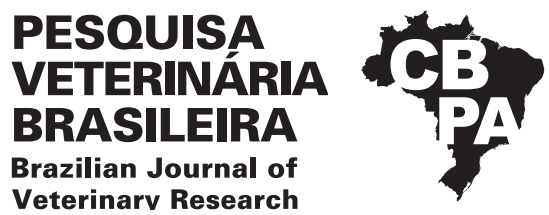

Pesq. Vet. Bras. 41:e06826, 2021 DOI: $10.1590 / 1678-5150-P V B-6826$

Original Article rinarv Research

ISSN 0100-736X (Print)

ISSN 1678-5150 (Online)

\title{
Hypomagnesemia in beef cattle ${ }^{1}$
}

\author{
Benjamín Doncel ${ }^{2,3}$, Juan D. Puentes ${ }^{3}$, Rubén D. Caffarena ${ }^{2,4}$, \\ Franklin Riet-Correa ${ }^{2,5}$ (D), Ricardo A. Costa ${ }^{2}$ and Federico Giannitti ${ }^{2 *}$ (D)
}

\begin{abstract}
Doncel B., Puentes J.D., Caffarena R.D., Riet-Correa F., Costa R.A. \& Giannitti F. 2021. Hypomagnesemia in beef cattle. Pesquisa Veterinária Brasileira 41:e06826, 2021. Plataforma de Investigación en Salud Animal, Instituto Nacional de Investigación Agropecuaria, Estación Experimental INIA La Estanzuela, Ruta 50 Km 11,39173, Colonia, Uruguay. E-mail: fgiannitti@inia.org.uy

Hypomagnesemia is a major cause of death in grazing beef cows in countries of the Southern Hemisphere such as Argentina, Australia and New Zealand. Here we review the literature on hypomagnesemia in beef cattle and describe an outbreak in Uruguay. The disease occurred in late autumn, affecting 6 to 11-year-old Aberdeen Angus and Hereford $x$ Aberdeen Angus lactating multiparous cows in good body condition, grazing on natural grasslands that had been improved by fertilization and sowing of seeds of ryegrass and oat. Approximately 40 out of 225 cows were affected and 24 (10.7\%) died. A presumptive diagnosis of hypomagnesemia was established based on sudden death, acute neuromuscular clinical signs, epidemiological data, and the response to $\mathrm{Mg}$ administration. The diagnosis was confirmed by detecting low Mg concentrations in serum $(0.47-0.57 \mathrm{mmol} / \mathrm{L})$, vitreous humor $(0.47-0.80 \mathrm{mmol} / \mathrm{L})$, aqueous humor $(0.66 \mathrm{mmol} / \mathrm{L})$ and cerebrospinal fluid $(0.59 \mathrm{mmol} / \mathrm{L})$. The largest component of the diet corresponding to fast-growing and exuberant forages of ryegrass and oat had high concentrations of $\mathrm{K}(3.48 \%), \mathrm{N}(4.38 \%)$ and $\mathrm{P}(0.94 \%)$, suggesting secondary hypomagnesemia. In addition, the $\mathrm{K} /(\mathrm{Ca}+\mathrm{Mg})$ ratio was 2.38 in forages of ryegrass and oat (reference value: 2.2 ), and 0.15 in the soil (reference value: 0.09 ), which represent risk factors for hypomagnesemia. In conclusion, hypomagnesemia is an important cause of mortality in beef cattle grazing improved natural grasslands in Uruguay and it can be easily prevented by correct seasonal Mg supplementation.
\end{abstract}

INDEX TERMS: Hypomagnesemia, grazing beef cattle, improved natural pastures, mortality, ryegrass, oat, Uruguay, cattle.

RESUMO.- [Hipomagnesemia em bovinos de corte.] A hipomagnesemia é uma das principais causas de morte em vacas de corte em pastagem em países do Hemisfério Sul, como Argentina, Austrália e Nova Zelândia. Aqui, revisamos

\footnotetext{
${ }^{1}$ Received on December 7, 2020.

Accepted for publication on December 21, 2020.

${ }^{2}$ Plataforma de Investigación en Salud Animal, Instituto Nacional de Investigación Agropecuaria (INIA), Estación Experimental INIA La Estanzuela, Ruta $50 \mathrm{Km} \mathrm{11,39173,} \mathrm{Colonia,} \mathrm{Uruguay.} \mathrm{*Corresponding} \mathrm{author:}$ fgiannitti@inia.org.uy

${ }^{3}$ Universidad Nacional de Colombia, Sede Bogotá, Facultad de Medicina Veterinaria y de Zootecnia, Laboratorio de Patología Veterinaria, Carrera 30 45-03, Edificio 502, Código postal 11001, Bogotá, Colombia.

${ }^{4}$ Departamento de Patología y Clínica de Rumiantes y Suinos, Facultad de Veterinaria, Universidad de la República (UdelaR), Montevideo, Uruguay.

${ }^{5}$ Graduate Program in Animal Science in the Tropics, Faculdade de Veterinária, Universidade Federal da Bahia (UFBA), Av. Adhemar de Barros 500, Ondina, Salvador, BA 40170-110, Brazil.
}

a literatura sobre hipomagnesemia em bovinos de corte e descrevemos um surto no Uruguai. A doença ocorreu no final do outono, afetando vacas Aberdeen Angus e Aberdeen Angus x Hereford de 6-11 anos de idade em boas condições corporais, lactantes, multíparas e pastando em campos naturais que foram melhorados com fertilização e plantio de azevém e aveia. Aproximadamente 40 de 225 vacas foram afetadas e $24(10,7 \%)$ morreram. 0 diagnóstico presuntivo de hipomagnesemia foi estabelecido com base na morte súbita, sinais clínicos neuromusculares agudos, dados epidemiológicos e a resposta à administração de Mg. O diagnóstico foi confirmado pela detecção de baixos níveis de $\mathrm{Mg}$ no soro $(0,47-0,57 \mathrm{mmol} / \mathrm{L})$, humor vítreo $(0,47-0,80 \mathrm{mmol} / \mathrm{L})$, humor aquoso $(0,66 \mathrm{mmol} / \mathrm{L})$ e líquido cefalorraquidiano $(0,59 \mathrm{mmol} / \mathrm{L})$. 0 componente mais importante da dieta correspondia a pastagens de azevém e aveia de rápido crescimento, as quais apresentaram altas concentrações de K $(3,48 \%)$, N $(4,38 \%)$ e P $(0,94 \%)$, que 
sugerem hipomagnesemia secundária. Além disso, a relação $\mathrm{K} /(\mathrm{Ca}+\mathrm{Mg})$ foi de 2,38 em forragens de azevém e aveia (valor de referência: 2,2) e 0,15 no solo (valor de referência: 0,09), que representam fatores de risco para hipomagnesemia. Em conclusão, a hipomagnesemia é uma causa importante de mortalidade em gado de corte em pastagens naturais melhoradas no Uruguai e pode ser facilmente prevenida pela correta suplementação sazonal de Mg.

TERMOS DE INDEXACÃO: Hipomagnesemia, gado de corte, pasto, pastagens naturais melhoradas, mortalidade, aveia, azevém, Uruguai, bovinos.

\section{INTRODUCTION}

Hypomagnesemia, also known as grass tetany, is a nutritional/ metabolic disease of ruminants that occurs in temperate countries with cold and wet climate (Burns \& Allcroft 1967, Allcroft \& Burns 1968), where grazed pastures are the main source of food for beef cattle production (Cseh \& Crenovich 1996). Hypomagnesemia is associated with improved pastures (Burns \& Allcroft 1967, Allcroft \& Burns 1968) and occurs when cows under intensive management practices graze on fast-growing grasses, particularly, but not exclusively, in the spring (Wilcox \& Hoff 1974). Hypomagnesemia mainly affects lactating (lactation tetany) (Grunes et al. 1970, Watson et al. 2008, Doncel et al. 2019) or pregnant dairy cows grazing lush, fast-growing winter grasses such as oat, wheat, or ryegrass. The disease also affects lactating and pregnant beef cattle (Metson et al. 1966, Grunes et al. 1970, Dutra 2009, 2010, Constable et al. 2017). Hypomagnesemia generally occurs when the grass is the only food source for cows during critical periods such as late pregnancy, calving and early lactation (Metson et al. 1966, Dutra 2009, 2010, Constable et al. 2017). Suckling or weaned calves may rarely be affected by dietary magnesium (Mg) deficiency (hypomagnesemic calf tetany) (Constable et al. 2017).

Hypomagnesemia is characterized by a reduced absorption of Mg (Kemp et al. 1961) and may be of primary or secondary nature. Hypomagnesemia of primary origin is due to a dietary deficiency of Mg (Constable et al. 2017). The concentration of $\mathrm{Mg}$ in the plant is partially determined by the level of exchangeable $\mathrm{Mg}$ in the soil (Metson 1974) and dietary $\mathrm{Mg}$ deficiency is associated with grasses in soils that have $0.2-0.3 \mathrm{meq}$ of exchangeable $\mathrm{Mg} / 100 \mathrm{~g}$ of plant roots (Welte \& Werner 1963). The use of fertilizers with nitrogen (N), phosphorus $(\mathrm{P})$ and potassium $(\mathrm{K})$ reduces the exchangeable $\mathrm{Mg}$ in the soil and the availability of $\mathrm{Mg}$ for the plants and, consequently, for the animals (Kemp et al. 1961, Grunes et al. 1970, Fox \& Piekielek 1984, Cohen et al. 2004, Elliott 2008, Kumssa et al. 2019).

Hypomagnesemia of secondary origin occurs when particular factors in the diet interfere with the ruminal absorption of $\mathrm{Mg}$ such as high concentrations of $\mathrm{K}$ and $\mathrm{N}$, or low levels of sodium (Na) (Metson et al. 1966, Fontenot et al. 1989, Martín-Tereso \& Martens 2014, Martens et al. 2018). The use of fertilizers such as N (Grunes \& Welch 1989, Macdonald et al. 2017), K and P (Kemp 1960, Metson et al. 1966, Wilkinson et al. 1987, Mayland \& Wilkinson 1989, Elliott 2009) increase forage production but also the levels of N, K and $\mathrm{P}$ in the forages, which interfere with the bioavailability of ruminal Mg (Metson et al. 1966, Wilkinson et al. 1987, Grunes
\& Welch 1989, Elliott 2008, Martín-Tereso \& Martens 2014). The main characteristic of fast-growing and lush grasses is the extremely high $\mathrm{N}$ content that range from $4.2 \%$ to $6.3 \%$ (equivalent to 26\%-39\% crude protein) and animals grazing on such grasses rapidly accumulate high concentrations of ammonium ion in the rumen, which increases the ruminal $\mathrm{pH}$ and reduces the bioavailability of $\mathrm{Mg}$ (Metson et al. 1966, Wilkinson et al. 1987).

In adult cows, $80-83 \%$ of the total Mg intake is eliminated in feces and only 17-20\% is absorbed (Kemp et al. 1961, Martens et al. 2018). The level of plasma $\mathrm{Mg}$ depends primarily on the influx of Mg from the forestomachs to the extracellular space and the efflux from the extracellular space into the secreted milk or to the fetus (Kemp et al. 1961). The animal uses approximately $5 \mathrm{~g}$ /day of absorbed $\mathrm{Mg}$ for maintenance (Kemp et al. 1961, Martens et al. 2018) and 0.12g/L of produced milk (Cerbulis \& Farrell 1976). The fetus requires $0.2 \mathrm{~g}$ /day in the last third of pregnancy (House \& Bell 1993). The surplus $\mathrm{Mg}$ absorbed from the diet is eliminated in the urine (Kemp et al. 1961, Martens et al. 2018). The level of $\mathrm{Mg}$ in the body depends directly on dietary intake and the renal excretion and is not regulated by hormones (Kemp et al. 1961, Martín-Tereso \& Martens 2014, Martens et al. 2018).

Outbreaks of hypomagnesemia have been described in beef cattle in Scotland (Burns \& Allcroft 1967), the USA (Haggard et al. 1978), Australia (Harris et al. 1983, Harris \& Hill 1997), New Zealand (Metson et al. 1966, McKenzie 1999), Canada (Odette 2005), England and Wales (Watson et al. 2008), Egypt (El-Sangary et al. 2011), Japan (Ishii et al. 2012), Italy (D’Angelo et al. 2015), Argentina (Cseh \& Crenovich 1996, Pechin et al. 2011, Cantón et al. 2014), Chile (Wittwer et al. 1997) and Uruguay (Dutra 2009, 2010). A number of risk factors have been associated with hypomagnesemia, including grazing fast-growing and lush forages in winter, reduced solar exposure of winter forages that may be accompanied by excess of rainfall, grazing on sprouts with high water, Kand/or protein content and low crude fiber (Cseh \& Crenovich 1996). In addition, several environmental and management factors may predispose to outbreaks of hypomagnesemia, including thunderstorms (Odette 2005), heavy rains, cloudy days, strong winds, low temperatures with sudden changes, high humidity, low solar radiation, prolonged confinement without access to food, prolonged transport, changes in diets for pregnant cows (Metson et al. 1966, Larvor 1976), decreased calcium (Ca) and $\mathrm{Na}$ in the diet (Rayssiguier 1977), estrus (Harris \& Hill 1997), lactation and calving, weaning, and crowding conditions (Dutra 2009, 2010, Cantón et al. 2014).

Hypomagnesemia appears to be severe in the presence of both nutritional factors and adverse weather conditions. Hypomagnesemia is common in cattle receiving low dietary content of $\mathrm{Mg}$, inadequate energy intake and cows shortly after calving during cold, wet and windy weather (Grunes et al. 1970, Constable et al. 2017). Outbreaks of hypomagnesemia in beef cattle occur in fat cows subjected to temporary low nutrition plane (Constable et al. 2017). In the northern USA, outbreaks of hypomagnesemia normally occur during periods of low barometric pressure when the ambient temperature ranges between 7 and $16^{\circ} \mathrm{C}$ and the soil temperature is below $7^{\circ} \mathrm{C}$ (Constable et al. 2017). In Buenos Aires province, Argentina, outbreaks of hypomagnesemia registered over two periods, one of 20 years and the second of 15 years, were reported to 
occur in temperate climate with an average temperature of 10.1 and $13.9^{\circ} \mathrm{C}$, annual rainfall of 821 to $988 \mathrm{~mm}$, and average solar radiation of 9.4 and $9.9 \mathrm{MJ} / \mathrm{m}^{2} /$ day (Cseh \& Crenovich 1996, Cantón et al. 2014). Although hypomagnesemia occurs in both beef and dairy cattle, it is the most prevalent disease in beef cattle in temperate zones (i.e. New Zealand, Australia and Argentina), where the condition is seen generally in a temperature range of approximately $4-16^{\circ} \mathrm{C}$ (Kemp \& $\mathrm{t}^{\prime} \mathrm{Hart}$ 1957, Metson et al. 1966, Burns \& Allcroft 1967, Cseh \& Crenovich 1996, Harris \& Hill 1997).

Hypomagnesemia occurs in beef cattle grazing pastures cultivated with perennial grasses, winter forages (Allcroft \& Burns 1968, Grunes \& Welch 1989), spring forages (Grunes et al. 1970, Wilcox \& Hoff 1974) or in native grasslands (Grunes et al. 1970, Cseh \& Crenovich 1996). Perennial grasses in which outbreaks of hypomagnesemia have been described include orchard grass (Dactylis glomerata) (Grunes et al. 1970, Cantón et al. 2014), perennial ryegrass (Lolium perenne) (Metson et al. 1966, Grunes et al. 1970, Ishii et al. 2012), desert wheatgrass (Agropyron desertorum) (Grunes et al. 1970), tall wheatgrass (Thinopyrum ponticum), fescue (Festuca arundinacea), phalaris (Phalaris tuberosa) and weeping lovegrass (Eragrostis curvula) (Grunes et al. 1970, Cseh \& Crenovich 1996, Pechin et al. 2011, Cantón et al. 2014). Fast-growing and lush winter and spring forages that may cause hypomagnesemia (Grunes et al. 1970, Bohman et al. 1983, Harris et al. 1983, Cseh \& Crenovich 1996, Harris \& Hill 1997, McKenzie 1999, Odette 2005) include annual ryegrass (Lolium rigidum and Lolium multiflorum), wheat (Triticum aestivum), oat (Avena sativa) (Bohman et al. 1983, Cantón et al. 2014), rye (Secale cereale) (Grunes et al. 1970, Brizuela \& Cseh 2003) and barley (Hordeum leporinum and Hordeum vulgare) (Grunes et al. 1970). The disease may also occur in fields with a variety of improved native forages (Cseh \& Crenovich 1996, Wittwer et al. 1997, Cantón et al. 2014). However, there is no consistent information on what improvements were made in the natural pastures where the disease occurred. In general, improved natural pastures are considered those with native vegetation that are fertilized, and seeds are introduced preserving the native vegetation (Risso \& Berretta 2001, Formoso 2010). Hypomagnesemia is also described in beef cattle grazing unimproved pastures with native forages (Cseh \& Crenovich 1996, Cantón et al. 2014), yet the predominant native species and the environmental conditions where these outbreaks occurred are unknown.

Hypomagnesemia in beef cattle is seasonal. In Australia it occurs in autumn (Harris et al. 1983, Harris \& Hill 1997) and in New Zealand in late winter and early spring (Metson et al. 1966, McKenzie 1999). In beef herds, the tendency of calving in autumn seems to increase the seasonal incidence of hypomagnesemia in late autumn (Allcroft \& Burns 1968, Elliott 2009). In Argentina, hypomagnesemia occurs more frequently from autumn to spring (Cseh \& Crenovich 1996) being more frequent from June to October (Cantón et al. 2014). In Uruguay outbreaks of hypomagnesemia have been reported in autumn and winter in April, June and August (Dutra $2009,2010)$. The time when cattle are more prone to develop hypomagnesemia coincides with the physiological stage of the cows, mainly when there is a higher Mg requirement for fetal growth (House \& Bell 1993) or milk production (Cerbulis \& Farrell 1976) in the last third of gestation (Harris \& Hill
1997, Cantón et al. 2014) or early lactation (Harris \& Hill 1997), respectively.

Susceptibility to hypomagnesemia in beef cattle varies with age, body condition, breed, and productive status. The disease is well recognized in pregnant cows about 7-10 days prepartum and cows in early lactation, and, less frequently, in cows between 30 and 60 days prepartum (McKenzie 1999). Lactating cows (Metson et al. 1966, Cseh \& Crenovich 1996, Cantón et al. 2014) or pregnant cows (Cseh \& Crenovich 1996, Dutra 2009, 2010) are more often affected. In Argentina, $70-73 \%$ of the affected cows were in the postpartum period and 25-26\% were pregnant cows (Cseh \& Crenovich 1996, Cantón et al. 2014). About 67-100\% of beef cows affected by hypomagnesemia are older than 6 years (Harris et al. 1983, Harris \& Hill 1997, Dutra 2009) and the highest number of deaths occurs within two weeks after parturition (Metson et al. 1966). Even though hypomagnesemia is more prevalent in older animals (Metson et al. 1966, Harris et al. 1983), younger categories are known to be affected as well (Metson et al. 1966, Haggard et al. 1978, Cseh \& Crenovich 1996, ElSangary et al. 2011, Cantón et al. 2014, D’Angelo et al. 2015).

In Australia, researchers found a lower incidence of hypomagnesemia in cows with moderate body condition $(1.7 \%)$ and a higher incidence in thin $(6.4 \%)$ and fat cows (2.4\%) (Harris et al. 1983). In contrast, in Argentina, from 173 outbreaks of hypomagnesemia reported in beef cattle, $50.9 \%$ affected cows with very good body condition, $43.9 \%$ affected cows with good body condition, and only $5.3 \%$ affected cows in fair body condition (Cantón et al. 2014). In Australia, hypomagnesemia is most common from June to August because cows are lactating and losing body condition (Harris et al. 1983, Harris \& Hill 1997) and this period coincides with adverse weather conditions (Henne 2013).

Hypomagnesemia in beef cattle has been described in the Aberdeen Angus (Harris et al. 1983, Greene et al. 1989, Cseh \& Crenovich 1996, Watson et al. 2008, Cantón et al. 2014), Hereford (Greene et al. 1986, Wittwer et al. 1997, Dutra 2009, 2010), Wagyū (Ishii et al. 2012), Charolais (Cantón et al. 2014) and Piedmontese (D'Angelo et al. 2015) breeds. British and European Bos taurus taurus cattle are more susceptible to hypomagnesemic grass tetany than zebu (Bos taurus indicus) cattle and their crosses (Harris \& Hill 1997, Greene et al. 1986).

The morbidity and mortality of hypomagnesemia in beef cattle are variable. In New Zealand, there were 19 outbreaks between August and September 1965 in the Hawke's Bay district with 14-37.5\% mortality (Metson et al. 1966). In southeastern Australia, from July to December 1980 the morbidity and mortality rates were $3.9 \%$ and $2.1 \%$ on 48 randomly selected beef cattle herds in Hampden and Heytesbury Shires, respectively (Harris et al. 1983). In Scotland, an incidence of hypomagnesemia of $10.9 \%$ was reported in a herd of beef cattle (Burns \& Allcroft 1967). In England and Wales, hypomagnesemia was diagnosed in $52.2 \%$ of 46 cases of sudden death of beef cows that were referred to the Veterinary Laboratories Agency in 2004 (Watson et al. 2008). In Egypt, a $10 \%$ mortality in calves was found in a study conducted to evaluate hypomagnesemia and its relationship with parathyroid hormone levels (El-Sangary et al. 2011). In Italy, a $41.9 \%$ frequency of hypomagnesemia was reported in a study on the causes of tonic-clonic seizures in 43 beef cattle referred to the Veterinary Teaching Hospital of the University 
of Turin from January 2002 to February 2014 (D'Angelo et al. 2015). In Argentina, episodes of hypomagnesemia were analyzed in beef cows registered in the Specialized Veterinary Diagnostic Service of the National Institute of Agricultural Technology (INTA) of Balcarce during two periods; one in 1972-1992 (20 years) included 64 outbreaks and the other from 1998 to 2013 (15 years) included 173 outbreaks. The average mortality by hypomagnesemia in both periods was 4\% and 3\%, respectively (Cseh \& Crenovich 1996, Cantón et al. 2014). In Uruguay, outbreaks of hypomagnesemia in beef cows have been described; one associated with prolonged transport with morbidity of $6.7 \%$, mortality of $5.7 \%$ and fatality of $85.7 \%$, and two outbreaks associated with prolonged confinement with morbidity of $8.3 \%$ and $45 \%$, mortality of $6.7 \%$ and $43 \%$, and fatality of $80 \%$ and $95.6 \%$, respectively (Dutra 2009, 2010).

Clinical hypomagnesemia in beef cattle occurs in acute, subacute and chronic forms (Constable et al. 2017) but sudden death is also described (Harris \& Hill 1997, Watson et al. 2008, Dewell \& Ensley 2016, Constable et al. 2017). In Argentina, clinical signs that are consistent with hypomagnesemia were described in $78.9 \%$ of 173 episodes, while in the remaining 21.1\% no signs were seen before death (Cantón et al. 2014). In England and Wales, hypomagnesemia was diagnosed in $52.2 \%$ beef (46) and 5.8\% dairy (77) cattle with sudden death (Watson et al. 2008). Although there is no comparative data of fatality rates in beef and dairy cattle, it is thought to be higher in beef cattle (Watson et al. 2008, Constable et al. 2017).

Acute hypomagnesemia has a highly variable short clinical course and death usually occurs within a few minutes to an hour (Metson et al. 1966, Odette 2005, Constable et al. 2017). In very acute cases death occurs in approximately 10 minutes (Grunes et al.1970). Generally, the most acute cases are designated as "sudden death" because dead animals are found with high frequency in herds of beef cattle where, unlike dairy cattle, the farm staff has sporadic contact with animals. In general, the initial clinical signs include hyperexcitability, incoordination and nervous apprehension. Occasionally the animals are seen grazing and suddenly adopt an unusual alert posture and appear uncomfortable or restless. There are facial muscle spasms, tetany at the base of the ears, hyperesthesia, spasticity, and occasional aggressiveness. The head may be raised, and the ears erected and/or the animal may have a fixed gaze. Mild disturbances precipitate episodes of continued loud bellowing, frenetic gallop, or unsteadiness. The animals appear weak, kick or run, the gait becomes wobbly, and there are stumbling, collapse and falling. Sometimes they stand up or remain in sternal or lateral recumbence because of tetany of the limb muscles. There also may be fine tetany of the muscles of the head and trembling of the face, neck and flanks. Those signs rapidly progress to violent tonic-clonic seizures with periods of relaxation. During convulsive episodes it is common to observe jaw chewing movements with grinding of the molars, foaming at the mouth and nose, exaggerated movements of the eyeballs, opisthotonos or violent pedaling movements. The animal can go into a coma usually between 6 and $10 \mathrm{~h}$ after the initial clinical signs and eventually die (Allcroft \& Burns 1968, Grunes et al. 1970, Haggard et al. 1978, Cseh \& Crenovich 1996, Harris \& Hill 1997, Odette 2005, Dutra 2009, 2010, El-Sangary et al. 2011, Dewell \& Ensley 2016, Constable et al. 2017).
Subacute hypomagnesemia has a clinical course of 3-4 days (Metson et al. 1966, Harris \& Hill 1997, Constable et al. 2017). Common clinical signs are reduced appetite, polyuria, spasmodic urination, frequent defecation, anxious facial expression, walking difficulties, hypermetria, trismus and sudden movements or bellowing (Metson et al. 1966, Harris \& Hill 1997, Dutra 2009, 2010, El-Sangary et al. 2011, Constable et al. 2017). Affected animals may recover spontaneously within a few days or progress to a prolonged sternal recumbence with unsuccessful attempts to stand-up and develop a syndrome similar but much milder than in the acute form (Constable et al. 2017).

Chronic hypomagnesemia can last for several weeks. Apathy, indifferent appetite, dullness, stiff gait and gradual loss of body condition are observed. The disease may progress and affected animals manifest clinical signs typical of those described for acute hypomagnesemia, or eventually recover (Grunes et al. 1970, Constable et al. 2017). Hypomagnesemia can be subclinical with $\mathrm{Mg}$ values lower than $0.7 \mathrm{mmol} / \mathrm{L}$ of serum (Cseh \& Crenovich 1996, Pechin et al. 2011, Constable et al. 2017). Cows do not lose their appetite, but milk production may decrease (Dewell \& Ensley 2016).

Hypomagnesemia is characterized biochemically by low blood $\mathrm{Mg}$ values. In cows, normal Mg levels range between $0.7-1.23 \mathrm{mmol} / \mathrm{L}$ of serum (Constable et al. 2017), 0.62-0.81 mmol/L of cerebrospinal fluid (McCoy et al. 2001), $0.73-0.79 \mathrm{mmol} / \mathrm{L}$ of aqueous humor and $0.84-0.90 \mathrm{mmol} / \mathrm{L}$ of vitreous humor (McCoy et al. 2001). Mg is stable in aqueous and vitreous humors until 24 and $48 \mathrm{~h}$ post mortem, respectively. Both fluids are used in the postmortem diagnosis of hypomagnesemia (McCoy 2004). Gross pathological findings consist of hemorrhages in the subcutaneous tissue, epicardium, endocardium, pleura, and intestinal mucosa (Odette 2005, Dutra 2009, 2010, Constable et al. 2017). Agonal pulmonary emphysema may be present (Constable et al. 2017) and perivascular hemorrhages may be observed in the brain and brainstem (Odette 2005, Dutra 2009, 2010).

Prophylactic measures for hypomagnesemic tetany include an integrated assessment of soil, forage, animals, and the environment to implement prevention strategies (Kumssa et al. 2019). Beef cows of British breeds (i.e. Aberdeen Angus, Hereford) or crosses in early lactation with a body weight of $500 \mathrm{~kg}$ consume $10.5 \mathrm{~kg}$ of dry matter (DM) per day and require $0.2 \%$ of Mg in DM (NRBC 2000, BCNS 2018). Similar cows fed ration require 21, 22 and 18g per day of dietary $\mathrm{Mg}$ in early, mid and late lactation, respectively, to maintain concentrations of $0.82 \mathrm{mmol} / \mathrm{L}$ in serum (O'kelley \& Fontenot 1969). In diets with $\mathrm{K}$ levels greater than 1\%, it is recommended to provide $0.35 \% \mathrm{Mg}$ in the total DM (NRBC 2000, Martín-Tereso \& Martens 2014). The sources of Mg used in the diet to supplement $\mathrm{Mg}$ in livestock are $\mathrm{Mg}$ oxide (MgO) with $55 \%$ of $\mathrm{Mg}$ bioavailability, $\mathrm{Mg}$ chloride $\left(\mathrm{MgCl}_{2}\right)$ with $12 \%$ bioavailability and $\mathrm{Mg}$ sulfate $\left(\mathrm{MgSO}_{4} 7 \mathrm{H}_{2} \mathrm{O}\right)$ with $10 \%$ of bioavailability of Mg (Goff 1999, Farmfact 2020).

The treatment of clinical cases includes $\mathrm{Mg}$ containing solutions administered intravenously, subcutaneously or orally (Goff 1999). It is recommended to administer 2-4g of Mg intravenously (Goff 1999, Martens \& Schweigel 2000). Alternatively, 200 to $400 \mathrm{ml}$ of a $25 \% \mathrm{Mg}$ sulfate $\left(\mathrm{MgSO}_{4} 7 \mathrm{H}_{2} \mathrm{O}\right)$ solution can be administered subcutaneously to a maximum of $100 \mathrm{ml}$ per injection site (Goff 1999). Treatment is 
unsuccessful when animals are in coma (Allcroft \& Burns 1968, Grunes et al. 1970). Oral administration of Mg salts can provide a longer maintenance of plasma Mg levels and is recommended once the animal has recovered esophageal reflexes so that the risk to develop aspiration pneumonia is reduced (Goff 1999). However, Mg administered by the oral route is not recommended for initial treatment due to the relatively slow absorption rate (Goff 1999). Intraruminal gavage of an aqueous solution containing $100 \mathrm{~g}$ of $\mathrm{MgO}$, mixed with $100 \mathrm{~g}$ of Ca chloride $\left(\mathrm{CaCl}_{2}\right)$ and $50 \mathrm{~g}$ of Na chloride $(\mathrm{NaCl})$ may enhance the effectiveness when hypocalcemia is also associated with hypomagnesemia. The addition of $\mathrm{Na}$ enhances the ruminal absorption of Mg (Goff 1999). Alternatively, $200 \mathrm{ml}$ of a $50 \%$ $\mathrm{MgSO}_{4} 7 \mathrm{H}_{2} \mathrm{O}$ solution administered intraruminally allows a quick recovery of blood $\mathrm{Mg}$ values because it is better absorbed than MgO (Goff 1999).

Hypomagnesemia in beef cattle is an underdiagnosed disease, which is necessary to establish differential diagnosis with other diseases that cause tetany, tremors and other nervous signs and/or death after an acute clinical course ("sudden death"). This work aims to describe an outbreak of hypomagnesemic tetany in beef cattle and to carry out a review of the literature. The reviewed information and the data provided are useful to establish correct diagnosis of the disease, to understand the epidemiological variables associated with the disease and the available methods of control and prophylaxis.

\section{MATERIALS AND METHODS}

A mortality outbreak affecting 24 lactating beef cows occurred within a week. Epidemiological data were obtained from the owner and the consulting veterinarian. Table 1 shows the cows that were studied, identified with numbers 1-8. Three cows (1-3) were necropsied. One of them was found alive and immediately subjected to a clinical exam and serum samples were collected before dying. Tissue samples from all three necropsied cows were collected, fixed for 48-72h in buffered formalin solution ( $\mathrm{pH} 7.4$ ), embedded in paraffin, cut into 3-4 $\mu \mathrm{m}$ thick sections and stained with hematoxylin and eosin (HE). One cow (4) in sternal decubitus with acute clinical signs and tetany was treated with Mg solution and the animal subsequently stood up and recovered. Cow 5 had been treated the day before and was found in lateral recumbence on the day of visit. A serum sample was collected, and the animal treated again with Mg solution but it finally died and was not necropsied. Cows 6-8 (Table 1) were found dead, Cow 6 had been previously treated, the other two (7 and 8) were not treated, all three had vitreous humor collected postmortem but they were not necropsied.

Serum samples from three cows (3-5, Table 1) with clinical signs were collected and submitted to the clinical pathology section of the Dirección de Laboratorios Veterinarios (DILAVE) for the determination of the concentration of $\mathrm{Ca}, \mathrm{P}$ and $\mathrm{Mg}$. Serum Ca was analyzed by the o-cresolphthalein complexone and 8-hydroxyquinoline procedure (Bazydlo et al. 2014). Serum P was measured with ammonium molybdate at $340 \mathrm{~nm}$ wavelength. The $\mathrm{Mg}$ concentration was determined by reaction with xylidyl blue (Wiener lab ${ }^{\circledR}$, Argentina) (Baginski et al. 1975, Bazydlo et al. 2014). Aqueous humor, vitreous humor and cerebrospinal fluid samples were collected and sent to DILAVE for the determination of $\mathrm{Mg}$ by the same method.

Pools of soil samples from the improved natural field where the mortality occurred, as well as grazed ryegrass and oat, diet supplements (oat hay and residues from the seed processing plant) and drinking water were collected and sent to the "Laboratorio de Suelos, Plantas y Agua del Instituto Nacional de Investigación Agropecuaria (INIA) La Estanzuela" for determination of N, K, Na, Ca, Mg and P.

Total $\mathrm{N}$ in the soil and $\mathrm{K}$ and $\mathrm{Na}$ in plants, soil and water were determined by atomic emission (Optima ${ }^{\mathrm{TM}} 7300$ DV Spectrometer, PerkinElmer $^{\circledR}$, USA) (Jackson 1964, INIA 2017), Ca and Mg in plants, soil and water were determined by atomic absorption (AAnalyst $700^{\mathrm{TM}}$ Spectrometer, PerkinElmer ${ }^{\circledR}$, USA). The available P was analyzed using the Bray technique, the samples were pretreated by wet digestion and the $\mathrm{P}$ was measured by colorimetric spectrophotometric analysis (Genesys $^{\mathrm{TM}}$ 10S VIS Spectrophotometer, Thermo Fisher Scientific ${ }^{\circledR}$, USA). In the drinking water, the $\mathrm{N}$ was determined by the Kjeldahl technique and the reactive $\mathrm{P}$ available by the spectrophotometric technique (INIA 2017).

In soil samples, the $\mathrm{K} /(\mathrm{Mg}+\mathrm{Ca})$ ratio expressed in meq/100g of soil, the risk of grass tetany (Elliott 2008) and the tetanizing potential (TP) (grass tetany index) of the diet were estimated by the following equation $\mathrm{TP}=1.53 \mathrm{xK} /(5 \mathrm{xMg}+3 \mathrm{xCa})$, using analytical concentrations of $\mathrm{K}, \mathrm{Mg}$ and $\mathrm{Ca}$, expressed in $\mathrm{g} / \mathrm{kg}$ or percentage of DM (Fiala \& Fialová 2018).

Table 1. Clinical history, Mg, Ca and P concentrations in serum, vitreous humor and cerebrospinal fluid of cows with clinical signs of hypomagnesemia that either died or responded to treatment with Mg solution

\begin{tabular}{|c|c|c|c|c|c|}
\hline Cow ID & History and response to treatment with $\mathrm{Mg}$ solution & Type of sample ${ }^{a}$ & $\begin{array}{c}\mathrm{Mg} \\
\mathrm{mmol} / \mathrm{L}^{\mathrm{b}}\end{array}$ & $\begin{array}{c}\mathrm{Ca} \\
\mathrm{mmol} / \mathrm{L}^{\mathrm{b}}\end{array}$ & $\begin{array}{c}\mathrm{P} \\
\mathrm{mmol} / \mathrm{L}^{\mathrm{b}}\end{array}$ \\
\hline 1 & Found dead without treatment, necropsied & VH & $0.54^{c}$ & - & - \\
\hline \multirow[t]{2}{*}{2} & Found dead without treatment, necropsied & VH & $0.75^{\mathrm{c}}$ & - & - \\
\hline & & CSF & 0.75 & - & - \\
\hline \multirow[t]{3}{*}{3} & Showed clinical signs, no treatment, necropsied & $\mathrm{AH}$ & $0.66^{\mathrm{c}}$ & - & - \\
\hline & & CSF & $0.59^{c}$ & - & - \\
\hline & & Serum & $0.45^{\mathrm{c}}$ & $1.59^{\mathrm{c}}$ & 1.92 \\
\hline 4 & Showed clinical signs, treated and recovered & Serum $^{\mathrm{d}}$ & 0.92 & $1.67^{\mathrm{c}}$ & 2.10 \\
\hline 5 & Showed clinical signs, treated, died & Serum & $0.57^{c}$ & $1.55^{\mathrm{c}}$ & 2.00 \\
\hline 6 & Showed clinical signs, treated, died & $\mathrm{VH}$ & $0.47^{\mathrm{c}}$ & - & - \\
\hline 7 & Found dead, not treated & VH & $0.80^{\mathrm{c}}$ & - & - \\
\hline 8 & Found dead, not treated & $\mathrm{VH}$ & $0.57^{\mathrm{c}}$ & - & - \\
\hline
\end{tabular}

${ }^{\mathrm{a}} \mathrm{VH}=$ vitreous humor, $\mathrm{CSF}=$ cerebrospinal fluid, $\mathrm{A} H=$ aqueous humor, ${ }^{\mathrm{b}}$ reference ranges in mmol/L and bibliographic references: Mg in VH 0.84-0.90, CSF 0.62-0.81 and AH 0.73-0.79 (McCoy et al. 2001), Mg 0.7-1.2, Ca 2.1-2.6 and P 1.4-2.6 in serum (Constable et al. 2017), ${ }^{\mathrm{C}}$ values are below the reference range, ${ }^{\mathrm{d}}$ collected post treatment. 
Climate information was collected from the meteorological databases of INIA and Colonia (Estación Meteorológica de Colonia 2020, INIA 2020). The environmental conditions at the time of visit to the farm, the herd management practices, and the evolution of the curative and preventive treatments were also evaluated.

\section{RESULTS}

The mortality outbreak in beef cattle occurred in an improved natural field located near Ombúes de la Lavalle (South Latitude 33.955, West Longitude 57.890), Colonia Department, Uruguay from June 4 to 10, 2018 (late autumn). The farm had agricultural and livestock activities. The 700ha agricultural area was used for the cultivation of grasses and legumes. The farm had its own seed processing plant dedicated to the production and commercialization of certified ryegrass, oat and soybean seeds. The livestock section was dedicated to the production of beef cattle. The affected herd had 225 calved Aberdeen Angus and Aberdeen Angus x Hereford beef cows, managed in a 45ha pasture.

The natural pasture was fertilized annually with 80$100 \mathrm{~kg} /$ ha of simple superphosphate and $80-120 \mathrm{~kg} / \mathrm{ha}$ of urea, enriched with sulfur (S), K, P and zinc (Zn). In the 45ha, approximately 25 tons of residues from the seed processing plant (oat, ryegrass and soybeans) were sowed annually, which included lower quality seeds to sprout as fast-growing and exuberant forages. At the time of the outbreak, annual oat and ryegrass were the main grasses available in the paddock, occupying approximately $60 \%$ of the pasture. The remaining $40 \%$ were native or naturalized grasses with a predominance of Cynodon dactylon, and, to a lesser extent, Paspalum spp. and Panicum prionitis.

The animals continuously grazed the fast-growing and lush pasture of ryegrass and oat, being the most abundant component of the diet. In addition, they were supplemented with approximately $400 \mathrm{~kg}$ of oat hay every three days, residues from the processing plant (unknown amount), and mineral salt and water ad libitum. The water came from a pond formed by damming a stream.

The weather conditions from May 30 to June 12, 2018 varied. The relative humidity was between $85-98 \%$, the daily temperature ranged from $8-15.5^{\circ} \mathrm{C}$, the solar radiation was $3.4-10.3 \mathrm{MJ} / \mathrm{m}^{2} /$ day, the wind speed was $69.9-613.8 \mathrm{~km} / 24 \mathrm{~h}$, the minimum temperature in the grass was $0.7-16.1^{\circ} \mathrm{C}$, the daily rainfall was $0-15.5 \mathrm{~mm}$, and the annual rainfall was $1234 \mathrm{~mm}$ (INIA 2020). The solar days varied with sudden changes within the 9:00h to 15:00h time period, being rainy, cloudy, partially clear or clear, and alternating days with clouds and clear sky (Estación Meteorológica de Colonia 2020). The ground of the paddock around the stream and the pond was humid, soft and the trampling of animals had formed abundant soft mud, making difficult for the animals to move. The forage supply in this section of the paddock was scarce and aggravated by trampling and difficult access. The
225 calving cows were in moderate heavy body condition and the stocking rate was high, approximately 5.5 animal units/ha according to the classification system of animal unit equivalents used in Uruguay (Saravia et al. 2011).

A total of 24/225 cows died (mortality: 10.7\%), 13 were Aberdeen Angus and 11 were Aberdeen Angus $\times$ Hereford crosses. The affected cows were in early lactation between 5-60d postpartum, multiparous, with 6 calvings on average, between 6 and 11-year-old, and 450kg of average body weight. Mortality began four days after the herd entered to the improved natural pasture. At the time of the consultation to the veterinary diagnostic laboratory, seven cows had died in $48 \mathrm{~h}$. The owners did not observe clinical signs, they only found dead cows.

The farm was visited three times. on the first visit, Cow 1 was necropsied and on the second visit to necropsy Cow 2 , a live Cow 3 was found in permanent lateral decubitus; the clinical examination revealed hyperesthesia, opisthotonos, erected ears, exophthalmia, involuntary movements of the ears and head, loud bellowing, trismus, hypersalivation, foaming at the mouth and nose, fasciculations of intercostal muscles, stiff limbs, seizures, and pedaling movements. The animal died 30 minutes later, and a necropsy was performed. Within a few minutes, three cows $(4,5$ and another not included in Table 1) fell in lateral or sternal recumbence and showed fasciculations of the muscles of the hind limbs, chewing movements, aggressiveness, raised head, alertness, hyperesthesia and difficulty standing up. When they were able to get up, showed gait difficulties, hypermetria, ataxia, excitement, hindquarter weakness, and staggering and stiffness of the limbs when walking. Occasionally the cows ran uncoordinatedly and fell off again. Rectal temperatures of Cows 4, 5 and another with clinical signs (not included in the Table 1 because the serum was hemolyzed and unsuitable for $\mathrm{Mg}$ testing) were normal $\left(37^{\circ} \mathrm{C}, 38.3^{\circ} \mathrm{C}\right.$ and $\left.37.9^{\circ} \mathrm{C}\right)$ and the respiratory rates were 48,38 and 51 movements per minute (tachypnea), respectively. Cow 4 recovered immediately after treatment, while Cow 5 died within approximately $8 \mathrm{~h}$ and the last cow died three days later. Three other cows were found dead on the same day.

Table 1 shows the Mg concentrations in the vitreous and aqueous humor collected from five cows that died from hypomagnesemia, and the values of $\mathrm{Mg}$, $\mathrm{Ca}$ and $\mathrm{P}$ in serum in three cows with clinical signs and the response to treatment with Mg solutions. The Mg values in the vitreous and aqueous humor were low in the dead cows (1-3, 5-8). The Mg value in the cerebrospinal fluid was low in one dead cow. The values of $\mathrm{Mg}$ in serum were low in all cows except 4, which recovered after treatment with $\mathrm{Mg}$ solution. Ca values in the serum of treated cows were low and $\mathrm{P}$ values were within normal limits. The values of $\mathrm{P}, \mathrm{Mg}, \mathrm{K}$ and the $\mathrm{K} /(\mathrm{Mg}+\mathrm{Ca})$ ratio in soil were high (Table 2).

Table 2. $\mathrm{Mg}, \mathrm{K}, \mathrm{N}, \mathrm{P}, \mathrm{Ca}$, and $\mathrm{Na}$ concentrations and the $\mathrm{K} /(\mathrm{Mg}+\mathrm{Ca})$ ratio in soil

\begin{tabular}{lccccccc}
\hline \multicolumn{1}{c}{ Sample } & $\mathrm{N} \%$ & $\mathrm{P} \mathrm{ppm}$ & Ca meq/100g & Mg meq/100g & $\mathrm{K} \mathrm{meq} / 100 \mathrm{~g}$ & $\mathrm{Na} \mathrm{meq} / 100 \mathrm{~g}$ & $\mathrm{~K} /(\mathrm{Mg}+\mathrm{Ca}) \mathrm{ratio}$ \\
\hline Pooled soil samples & 0.17 & $85.7^{\mathrm{a}}$ & 8.57 & $3.1^{\mathrm{a}}$ & $1.7^{\mathrm{a}}$ & 4.71 & $0.15^{\mathrm{a}}$ \\
Reference values & $0.15-0.25 \%^{\mathrm{b}}$ & $20-40^{\mathrm{c}}$ & $5-10^{\mathrm{b}}$ & $>1.5 \mathrm{high}$ & $0.4-0.6^{\mathrm{c}}$ & $2.79-5.56^{\mathrm{b}}$ & $>0.09^{\mathrm{d}}$ \\
\hline
\end{tabular}

${ }^{a}$ Values are high, ${ }^{b}$ Horneck et al. (2011), Hazelton \& Murphy (2016), ${ }^{c}$ Horneck et al. (2011), ${ }^{d}$ values over this limit represent a risk for hypomagnesemia (Elliott 2008). 
Table 3 shows the levels of $\mathrm{N}, \mathrm{P}, \mathrm{Mg}$ and $\mathrm{K}$ in the diet, which were high in the fast-growing and exuberant forages of ryegrass and oat. The values of $\mathrm{N}$ and $\mathrm{P}$ were high in clean residues of the seed processing plant. The values of $\mathrm{P}, \mathrm{K}$ and $\mathrm{Na}$ were high in the drinking water, while the $\mathrm{Mg}$ was low in the drinking water and oat hay. The TP of the fast-growing and lush forage of ryegrass and oat, clean residues from seed processing plant and oat hay was 2.38, 0.17 and 1.18, respectively.

A cow with clinical signs and in recumbence was treated with $60 \mathrm{~g}$ of Ca borogluconate solution, $5 \mathrm{~g}$ of Ca glycerate and $3.75 \mathrm{~g}$ of $\mathrm{Mg}$ sulfate administered intravenously. Immediately after treatment the cow stand up and walked away. Based on the response to treatment, it was recommended to use $4 \mathrm{~g}$ of Mg intravenously, which was repeated every 24h; meanwhile, oral supplementation of $\mathrm{Mg}$ was started. From that afternoon to the next day, the farm workers found nine dead cows, seven in recumbence and other cows with characteristic clinical signs of hypomagnesemia that were treated with intravenous and subcutaneous Mg solutions. Some of the treated cows recovered but six died after a clinical manifestation period of 12-48h. According to the staff the lack of success in the treatment was partially due to deficient skills in performing the venipuncture. The veterinarian reported a positive response to $\mathrm{Mg}$ treatment in the animals. The mortality and the occurrence of new clinical cases of hypomagnesemia were controlled by implementing preventive supplementation with $36 \mathrm{~g}$ of $\mathrm{MgO} / \mathrm{cow} /$ day in the ration. According to the farm staff, approximately 40 cows developed the disease (morbidity: $17.8 \%$ ) and 16 successfully recovered. whereas the fatality risk was 60\% (24/40).

The three necropsied cows showed carcasses in moderate heavy body condition ( 6 on a scale of 1 to 8 ), and abundant fat reserves. Multiple petechiae and ecchymoses were observed in the spleen capsule, epicardium, endocardium, subcutaneous tissue and lung pleura. No lesions were observed in other organs. Microscopically, the only lesions were hemorrhages in the same tissues mentioned at necropsy, there were no histological lesions of diagnostic value in other tissues.

\section{DISCUSSION}

The presumptive diagnosis of hypomagnesemia was made based on epidemiological findings, acute clinical signs followed by death and positive response to injectable treatment with Mg solutions and Mg supplementation in the diet. Low Mg values in serum, vitreous humor, cerebrospinal fluid and aqueous humor confirmed the diagnosis.

The high values of $\mathrm{N}, \mathrm{P}$ and $\mathrm{K}$, and the $\mathrm{K} /(\mathrm{Mg}+\mathrm{Ca})$ ratio greater than 2.2 in the ryegrass and oat forages, which were the main components of the diet, were suggestive of secondary hypomagnesemia. The high concentrations of $\mathrm{P}$ and $\mathrm{K}$, and the $\mathrm{K} /(\mathrm{Mg}+\mathrm{Ca})$ ratio greater than 0.09 in the soil supported the risk of grass tetany. High concentrations of $\mathrm{N}$ and $\mathrm{P}$ in residues from the seed processing plant and high concentrations of $\mathrm{P}$ and $\mathrm{K}$ in water possibly contributed to hypomagnesemia.

Secondary hypomagnesemia is caused by interference in ruminal absorption of Mg due to high concentrations of $\mathrm{P}, \mathrm{N}$ or $\mathrm{K}$ in the diet (Kemp et al. 1961, Metson et al. 1966, Mayland \& Grunes 1979, Cohen et al. 2004, Elliott 2008, Constable et al. 2017). The outbreak of hypomagnesemia in beef cattle described in this work was considered secondary because the animals grazed natural grasslands that had been improved with oat and ryegrass crops, fertilized annually with P, urea, $\mathrm{K}$ and abundant residues from the seed processing plant present in the farm. Cow grazing forages in soils with high concentrations of K are at risk to developing hypomagnesemia (Mayland \& Grunes 1979, Cohen et al. 2004). High K values in the soil reduce the absorption of $\mathrm{Mg}$ by the plant (Metson et al. 1966, Ohno et al. 1985), since K is more reactive and absorbed faster than Mg (Mayland \& Wilkinson 1989, Elliott 2008). In the case presented here, the $\mathrm{K} /(\mathrm{Mg}+\mathrm{Ca})$ ratio in the soil was 0.15 , which is greater than the reference value (0.09), indicating that it is a risk factor for cattle to develop grass tetany (Elliott 2008).

In Uruguay, hypomagnesemia was described in dairy cattle grazing lush, fast-growing forages in autumn (Doncel et al. 2019). In beef cattle, an outbreak of hypomagnesemia occurred in association with prolonged transport without access to feed and water (Dutra 2009) and two other outbreaks occurred after confinement for long periods in pens without access to water and feed (Dutra 2010). The data reported in this study and hypomagnesemia reported in beef cattle from different regions of the world (Metson et al. 1966, Allcroft \& Burns 1968, Haggard et al. 1978, Harris et al. 1983, Cseh \& Crenovich 1996, Wittwer et al. 1997, Odette 2005, Watson et al. 2008, El-Sangary et al. 2011, Ishii et al. 2012, Cantón et al. 2014, D'Angelo et al. 2015) suggest that the disease is common in temperate climate regions and that it may be underdiagnosed.

The differential diagnosis should include diseases that cause sudden death, tetany and/or tremors. In this outbreak, 11 cows were reported as sudden death as they did not show clinical signs. Sudden death is difficult to define, and some authors report sudden death when the animals appear dead without the observation of any clinical signs (Carramenha \& Carregaro 2012). However, this concept is not well defined, because, depending on the type of cattle production (free ranging or feedlot beef cattle, dairy cattle) the herd is checked out with different frequency and many clinical signs can go unnoticed. Sudden death or death without observing clinical

Table 3. $\mathrm{N}, \mathrm{P}, \mathrm{Ca}, \mathrm{Mg}, \mathrm{K}$, Na concentrations and the $\mathrm{K} /(\mathrm{Mg}+\mathrm{Ca})$ ratio of the diet

\begin{tabular}{|c|c|c|c|c|c|c|c|}
\hline Component & $\mathrm{N} \%$ & $\mathrm{P} \%$ & $\mathrm{Ca} \%$ & Mg \% & $\mathrm{K} \%$ & $\mathrm{Na} \%$ & $\mathrm{~K} /(\mathrm{Mg}+\mathrm{Ca})$ ratio \\
\hline Seed plant residue & $2.61^{\mathrm{a}}$ & $0.704^{\mathrm{a}}$ & 0.97 & $0.29^{a}$ & 0.48 & 0.16 & 0.17 \\
\hline Ryegrass and oat & $4.38^{\mathrm{a}}$ & $0.94^{\mathrm{a}}$ & 0.33 & $0.25^{\mathrm{a}}$ & $3.48^{\mathrm{a}}$ & 0.97 & $2.38^{\mathrm{a}}$ \\
\hline Oat hay & 0.29 & 0.099 & 0.14 & $0.04^{\mathrm{b}}$ & 0.48 & 1.46 & 1.18 \\
\hline Water & 0.00029 & $0.000048^{a}$ & 0.00298 & $0.00059^{\mathrm{b}}$ & $0.00069^{a}$ & $0.00461^{\mathrm{a}}$ & - \\
\hline
\end{tabular}

Reference values (\%) $\quad$ Ryegrass and oat ${ }^{c}: \mathrm{N}(1.88-2.5), \mathrm{P}(0.29-0.32), \mathrm{Ca}(0.37-0.43), \mathrm{Mg}(0.17-0.21)$, and Na (0.92-1.86); Oat hay ${ }^{\mathrm{d}}$ : Mg 0.51; drinking water ${ }^{\mathrm{e}}$ : P 0.00001, Ca 0.003, Mg 0.0009, K 0.0005, and Na 0.0038.

${ }^{\mathrm{a}}$ Values are high, ${ }^{\mathrm{b}}$ low values, ${ }^{\mathrm{c}}$ Formoso (2010), ${ }^{\mathrm{d}}$ Blackwood (2007), ${ }^{\mathrm{e}}$ Pehrsson et al. (2008). 
signs is described in several reports of hypomagnesemia in beef cattle (Odette 2005, Watson et al. 2008, Cantón et al. 2014). In acute cases of hypomagnesemia death may occur within less than 10 minutes of the onset of clinical signs (Grunes et al. 1970). In any case, the deaths after a clinical course of a few minutes observed in some cases of this study can be defined as sudden death. In Uruguay, the most frequent causes of sudden death in cattle, which must be differentiated from hypomagnesemia in beef cattle, include ruminal bloat (Moraes et al. 1993, Rivero et al. 2000), poisonings by plants containing hydrocyanic acid or nitrites and nitrates (Riet-Correa et al. 2009, García y Santos \& Capelli 2016), organophosphorus compounds or chlorinated insecticides, urea, ionophore antibiotics, electrocution by lightning or electric shock (Constable et al. 2017), vitamin E and selenium deficiency (Rivero et al. 1989, Rodríguez et al. 2018) and some infectious diseases such as anthrax (Bacillus anthracis), blackleg (Clostridium chauvoei) (Matto et al. 2009) and bacillary hemoglobinuria (Clostridium haemolyticum) (Navarro et al. 2017). Plants containing fluoroacetic acid, which in other countries are the main cause of sudden death associated with exercise (Vasconcelos et al 2008, Riet-Correa et al. 2009, Lee et al. 2012, Lima et al. 2016, Arruda et al. 2017) have not been described in Uruguay.

Another group of diseases that can be confused with hypomagnesemia are those that cause tremorgenic syndrome, which in Uruguay include intoxication by Paspalum spp. infected by Claviceps paspali and intoxication by Cynodon dactylon infected by Claviceps cynodontis (Rivero et al. 2000). These mycotoxicoses differ from hypomagnesemia by the low mortality with spontaneous regression of clinical signs upon stopping the ingestion of the toxic principle.

Another common clinical sign observed in animals from this outbreak was tetany, similar to that reported by other authors (Metson et al. 1966, Grunes et al. 1970, Haggard et al. 1978, Cseh \& Crenovich 1996, Wittwer et al. 1997, Dutra 2009, Dutra 2010, El-Sangary et al. 2011, Ishii et al. 2012, Constable et al. 2017). Among the diseases that cause tetany, the most frequent is tetanus, which in conditions of collective trauma can affect several animals (Rivero et al. 1989, Abd El-Moez et al. 2013). In tetanus, the clinical course is longer, and the clinical signs are characteristic and irreversible. Hypomagnesemia must be differentiated from some diseases of the nervous system, mainly ketosis occurring in pregnant and fat beef cows subjected to food deficiency during the last phase of pregnancy (Caplen et al. 1977, Rivero et al. 1989, Riet-Correa et al. 1990). Other diseases that must be differentiated from hypomagnesemia are rabies (Constable et al. 2017), acute lead poisoning (Blanc et al. 1999) and polioencephalomalacia (Rivero et al. 1989).

Some cows with clinical signs responded well to treatment with commercial intravenous Mg solutions as previously recommended (Goff 1999), but others did not recover, probably because the concentrations of $\mathrm{Mg}$ in the cerebrospinal fluid did not reach normal levels (Constable et al. 2017).

In Uruguay, raising beef cattle in improved natural grasslands is a common practice (Saravia et al. 2011). Natural grasslands are improved through the introduction of forage grasses such as ryegrass, oat, rye and fescue, and legumes such as alfalfa and clovers accompanied by fertilization (Risso \& Berretta 2001, Rodríguez \& Jacobo 2012). These pastures are more productive and allow to increase the stocking rate (Saravia et al. 2011). Prevention of hypomagnesemia in beef cattle raised in improved pastures should include a comprehensive assessment of the soil, forage, animal and the environment (Kumssa et al. 2019), and effective prevention is achieved by ensuring adequate blood Mg levels by supplementing with dietary Mg (Martens \& Blume 1986, Moseley \& Baker 1991, Wittwer et al. 1997, Martín-Tereso \& Martens 2014). Additionally, the growing practice of improving natural grasslands to intensify beef cattle production, suggests the need to include nutritional measures to prevent the disease, mainly in late autumn, winter and early spring.

The NRBC (2000) indicates that the Mg requirements for a $500 \mathrm{~kg}$ beef cow in early lactation are $0.2 \%$ of $\mathrm{Mg}$ in $10.5 \mathrm{~kg}$ of DM. Assuming that the diet has high levels of $\mathrm{N}$ and $\mathrm{K}$, it is recommended to administer $0.35 \%$ Mg in DM (Martín-Tereso $\&$ Martens 2014). The cows in the outbreak described here were Aberdeen Angus and some crosses with Hereford in early lactation, weighing approximately $450 \mathrm{~kg}$. Approximately $37 \mathrm{~g}$ of $\mathrm{Mg}$ per cow are required daily and given that a diet based on fast-growing and exuberant forages of ryegrass and oat provides approximately $0.17 \mathrm{~g}$ of $\mathrm{Mg}$ per $\mathrm{kg}$ of DM (Formoso 2010) and from the DM intake, it is concluded that fast-growing and exuberant forages provide $18 \mathrm{~g}$ of $\mathrm{Mg}$, therefore, $19 \mathrm{~g}$ of Mg per cow should be supplemented daily. Using $\mathrm{MgO}$ as a source of $\mathrm{Mg}$ (Wittwer et al. 1997, Urdaz et al. 2003, Farmfact 2020), a total of $36 \mathrm{~g}$ of $\mathrm{MgO}$ are required in the diet per cow daily either in the ration or mixed with salt. Additionally, it is recommended to improve the food supply, adjusting the appropriate stocking rate, and to reduce stressors such as the movement of animals, long periods of starving or low forage supply and grazing on soft, muddy or buried terrain. In cows at peripartum and early lactation occurring from June to October it is convenient to avoid fattened cows at calving and to reduce the movements for long periods or prolonged starving under confinement conditions (Dutra 2009, Elliott 2009, Cantón et al. 2014).

\section{CONCLUSION}

Hypomagnesemia causes mortality in beef cows in Uruguay grazing on natural grasslands that had been improved by fertilization and introduction of lush, fast-growing grasses. Hypomagnesemia is easily prevented by correct supplementation of $\mathrm{Mg}$ in the diet.

Acknowledgments.- The authors thank INIA, Uruguay for supporting this study. This work was financed by project PL_27 N-23398 and the postgraduate scholarship 1070-2018. The authors thank Yisell Perdomo, Cecilia Monesiglio and Anderson Saravia from INIA La Estanzuela for their technical assistance. To Dr. Jorge Slavica and Sebastian Rochón for the epidemiological data.

Conflict of interest statement.- The authors declare that they have no conflicts of interest.

\section{REFERENCES}

Abd El-Moez S.I., Ata N.S., Mona S. \& Zaki M.S. 2013. Bacterial causes of sudden death in farm animals. Life Sci. J. 10(1):1188-1201.

Allcroft R. \& Burns K.N. 1968. Hypomagnesaemia in cattle. N. Z. Vet. J. 16(7):109-128. <https://dx.doi.org/10.1080/00480169.1968.33757> <PMid:4884842> 
Arruda F.P., Caldeira F.H.P., Ducatti K.R., Bezerra K.S., Marcolongo-Pereira C., Lee S.T., Cook D., Riet-Correa F. \& Colodel E.M. 2017. Experimental poisoning of Niedenzuella stannea (Malpighiaceae) in cattle and corresponding detection of monofluoroacetate. Ciência Rural 47(3):1-6. <https://dx.doi. org/10.1590/0103-8478cr20160761>

Baginski E.S., Eptein E. \& Zak B. 1975. Review of phosphate methodologies. Ann. Clin. Lab. Sci. 5(5):399-416. <PMid:1180482>

Bazydlo L.A.L., Needham M. \& Harris N.S. 2014. Review. Calcium, magnesium, and phosphate. Lab. Med. 45(1):e44-e50. <https://dx.doi.org/10.1309/ LMGLMZ8CIYMFNOGX>

BCNS 2018. Beef Cattle Nutrition Series. Part 3: Nutrient Requirement Tables. MP391, University of Arkansas, Arkansas. 28p.

Blackwood I. 2007. Mineral content of common ruminant stockfeeds, crops and pastures. NSW Department of Primary Industries, Primefacts 522:1-7.

Blanc J., Rivero R., Rampoldi O., Moraes J. \& Kautz S. 1999. Intoxicación por plomo en vacas Holando. XXVII Jornadas Uruguayas de Buiatría, Paysandú, Uruguay, p.43-45.

Bohman V.R., Horn F.P., Stewart B.A., Mathers A.C. \& Grunnes D.L. 1983. Wheat pasture poisoning. I. An evaluation of cereal pastures as related to tetany in beef cows. J. Anim. Sci. 57(6):1352-1363. <https://dx.doi.org/10.2527/ jas1983.5761352x> <PMid:6674278>

Brizuela M.A. \& Cseh S.B. 2003. Composición mineral y potencial tetanizante de verdeos de invierno sembrados en diferentes fechas. Revta Arg. Prod. Anim. 23(2):91-101.

Burns K.N. \& Allcroft R. 1967. Hypomagnesaemic tetany in cattle. I. Incidence, aetiology, diagnosis and treatment. Br.Vet.J.123(8):340-348. <PMid:5624388>

Cantón G., Odriozola E. \& Cseh S. 2014. Análisis de casos de hipomagnesemia en bovinos de producción de carne diagnosticados en INTA EEA Balcarce (1998-2013).XX Reunión Científica Técnica, Tucumán, Argentina. (Abstract).

Caplen I.W., Pemberton D.H., Harrinson M.A. \& Halpin C.G. 1977. Starvation ketosis in pregnant beef cows. Aust. Vet. J. 53(6):289-291.<https://dx.doi. org/10.1111/j.1751-0813.1977.tb00220.x><PMid:901336>

Carramenha C.P. \& Carregaro A.B. 2012. Stress and sudden death in veterinary medicine. Ars Vet. 28(2):90-99. <https://dx.doi.org/10.15361/21750106.2012v28n2p090-099>

Cerbulis J. \& Farrell Jr H.M. 1976. Composition of the milk of dairy cows. II. Ash, calcium, magnesium, and phosphorous. J. Dairy Sci. 59(4):589-593. <https://dx.doi.org/10.3168/jds.S0022-0302(76)84245-2><PMid:1262573>

Cohen R.D.H., Wright S.B.M., Thomas L.R., McCaughey W.P. \& Howard M.D. 2004. Current and residual effects of nitrogen fertilizer applied to grass pasture on production of beef cattle in central Saskatchewan. Can. J. Anim. Sci. 84(1):91-104. <https://dx.doi.org/10.4141/A03-050>

Constable P.D., Hinchcliff K.W., Done S.H. \& Grünberg W. 2017. Veterinary Medicine. 11th ed. Saunders Elsevier, St. Louis, Missouri, p.1488, 1662-1706.

Cseh S.B. \& Crenovich H. 1996. Hipomagnesemia en el Sudeste de la Provincia de Buenos Aires, Argentina. Arch. Med. Vet. 28(2):111-116.

D’Angelo A., Bellino C., Bertone I., Cagnotti G., Iulini B., Miniscalco B., Casalone C., Gianella P. \& Cagnasso A. 2015. Seizure disorders in 43 cattle. J. Vet. Intern. Med. 29(3):967-971. <https://dx.doi.org/10.1111/jvim.12592> $<$ PMid:25857732>

Dewell G. \& Ensley S. 2016. Hypomagnesaemia (grass tetany) in beef cattle. PMR1020, Extension and Outreach, Iowa State University. Available at <https:// store.extension.iastate.edu/product/14522> Accessed on Jul. 24, 2020.

Doncel B., Capelesso A., Giannitti F., Cajarville C., Macías M., Silveira C., Costa A.R. \& Riet-Correa F. 2019. Hipomagnesemia en ganado lechero en Uruguay. Pesq. Vet. Bras. 39(8):564-572.<https://dx.doi.org/10.1590/1678-5150-pvb-6215>

Dutra F. 2009. Tetania del transporte. Arch. Vet. Este 2:6-7.

Dutra F. 2010. Tetania del destete. Arch. Vet. Este 2:10-11.
Elliott M. 2008. Grass tetany in cattle - predicting its likelihood. NSW Department of Primary Industries, Primefacts 785:1-6.

Elliott M. 2009. Grass Tetany in cattle: treatment and prevention. NSW Department of Primary Industries, Primefacts 421:1-4.

El-Sangary F.H., El-Barawy A.M., Faris A. \& El-Hamied S.S.A. 2011. Hypomagnesemia in beef calves at its relation with parathyroid hormone level. Assiut Vet. Med. J. 57(131):300-311.

Estación Meteorológica de Colonia 2020. Clima en Ombúes de Lavalle. Base de Datos Climáticos. Available at <https://freemeteo.es/eltiempo/ ombues-de-lavalle/historial/historial-diario/?gid=3441442\&date $=2018$ 06-04\&station $=23408 \&$ language $=$ spanish $\&$ country $=$ uruguay $>$ Accessed on Sep. 14, 2020.

Farmfact 2020. Magnesium supplementation. Farmfact (3-1), DairyNZ. 4p. Available at <https://www.dairynz.co.nz/media/5793092/3-1_magnesium supplementation-farmfact-v-42.pdf> Accessed on Aug. 26, 2020.

Fiala K. \& Fialová G. 2018. Pastevní tetanie - 60 let známého (?) poměru. III. Výpočet tetanickěho faktoru, dvojnásobně pozitivn alarmisté a mimotechnické onucky pana $\mathrm{K}^{*} \mathrm{~A}^{*} \mathrm{P}^{*} \mathrm{~L}^{*} \mathrm{~A}^{*} \mathrm{~N}^{*} \mathrm{~A}$. Výzkum $\mathrm{v}$ chovu skotu/ Cattle Research 221(3):15-23.

Fontenot J.P., Allen V.G., Bunce G.E. \& Goff J.P. 1989. Factors influencing magnesium absorption and metabolism in ruminants. J. Anim. Sci. 67(12):3445-3455. <https://dx.doi.org/10.2527/jas1989.67123445x> $<$ PMid:2693419>

Formoso F. 2010 Producción de Forraje y Calidad de Verdeos de Invierno y otras Alternativas de Producción Otoño-Invernales. Unidad de Comunicación y Transferencia de Tecnología de INIA, Montevideo, p.1-18, 38-104.

Fox R.H. \& Piekielek W.P. 1984. Soil magnesium level, corn (Zea mays L.) yield, and magnesium uptake. Commun. Soil Sci. Plant Anal. 15(2):109-123. <https://dx.doi.org/10.1080/00103628409367459>

García y Santos C. \& Capelli A. 2016. Intoxicaciones por plantas y micotoxinas en rumiantes diagnosticadas en Uruguay. Veterinaria, Montevideo, 52(201):28-42

Goff J.P. 1999. Treatment of calcium, phosphorus, and magnesium balance disorders. Vet. Clin. N. Am., Food Anim. Pract. 15(3):619-639. <https://dx.doi.org/10.1016/s0749-0720(15)30167-5><PMid:10573815>

Greene L.W., Baker J.F. \& Hardt P.F. 1989. Use of animal breeds and breeding to overcome the incidence of grass tetany: a review. J. Anim. Sci. 67(12):34633469. <https://dx.doi.org/10.2527/jas1989.67123463x><PMid:2693421>

Greene L.W., Solis J.C., Byers F.M. \& Schelling G.T. 1986. Apparent and true digestibility of magnesium in mature cows of five breeds and their crosses. J. Anim. Sci. 63(1):189-196. <https://dx.doi.org/10.2527/jas1986.631189x>

Grunes D.L. \& Welch R.M. 1989. Plant contents of magnesium, calcium and potassium in relation to ruminant nutrition. J. Anim. Sci. 67(12):3485-3494. <https://dx.doi.org/10.2527/jas1989.67123485x> <PMid:2693423>

Grunes D.L., Stout P.R. \& Brownell J.R. 1970. Grass tetany of ruminants. Adv. Agron. 22:331-374. <https://dx.doi.org/10.1016/S0065-2113(08)60272-2>

Haggard D.L., Whitehair C.K. \& Langham R.F. 1978. Tetany associated with magnesium deficiency in suckling beef calves. J. Am. Vet. Med. Assoc. 172(4):495-497. <PMid:624672>

Harris D. \& Hill S. 1997. Grass tetany (hypomagnesaemia) in beef cattle. AG0579, Agriculture Notes, Victoria Department of Primary Industries, Australia. Available at <https://webarchive.nla.gov.au/awa/20051115055023/ http://pandora.nla.gov.au/pan/54047/20051115-0000/AG0579.pdf> Accessed on Sep. 12, 2020.

Harris D.J., Lambell R.G. \& Oliver C.J. 1983. Factors predisposing dairy and beef cows to grass tetany. Aust. Vet. J. 60(8):230-234. <https://dx.doi. org/10.1111/j.1751-0813.1983.tb05970.x ><PMid:6639526>

Hazelton P. \& Murphy B. 2016. Interpreting Soil Test Results: What do all the numbers mean? CSIRO Publishing, Victoria, p.73-119. 
Henne K. 2013. Grass tetany. Victoria Farmer Federation. Livestock factsheet. p1-2. Available at <https://www.vff.org.au/vff/Documents/Factsheet Livestock_Grass\%20Tetany.pdf> Accessed on Sep. 12, 2020.

Horneck D.A., Sullivan D.M., Owen J.S. \& Hart J.M. 2011. Soil Test Interpretation Guide. EC1478, Extension Service Publications and Multimedia Catalog, Oregon State University. Available at <https://catalog.extension.oregonstate. edu/ec1478> Accessed on Mar. 16, 2020

House W.A. \& Bell A.W. 1993. Mineral accretion in the fetus and adnexa during late gestation in Holstein cows. J. Dairy Sci. 76(10):2999-3010. <https://dx.doi.org/10.3168/jds.S0022-0302(93)77639-0>

INIA 2017. Carpeta de Técnicas Oficiales. Laboratorio de Suelos, Plantas y Aguas, Instituto Nacional de Investigación Agropecuaria (INIA) La Estanzuela, Uruguay.

INIA 2020. Unidad de Agro-clima y Sistemas de Información (GRAS). Banco de Datos Agroclimáticos. Available at <http://www.inia.uy/gras/Clima/ Banco-datos-agroclimatico> Accessed on Sep. 14, 2020.

Ishii T., Sakaguchi Z., Koreeda T., Moriki H., Tabara N. \& Yamanaka N. 2012. A case of ryegrass staggers induced by imported straw in Japanese black cows. J. Jpn. Vet. Med. Assoc. 65(10):762-766. <https://dx.doi.org/10.12935/ jvma.65.762>

Jackson M.L. 1964. Análisis Químico de Suelos. Omega., Barcelona, p.662.

Kemp A. \& t'Hart M.L. 1957. Grass tetany in grazing milking cows. Neth. J. Agric. Sci. 5(1):4-17. <https://dx.doi.org/10.18174/njas.v5i1.17745>

Kemp A. 1960. Hypomagnesaemia in milking cows: the response of serum magnesium to alterations in herbage composition resulting from potash and nitrogen dressings on pasture. Neth. J. Agric. Sci. 8(4):281-304. <https:// dx.doi.org/10.18174/njas.v8i4.17642>

Kemp A., Deijs W.B., Hemkes O.J. \& Van Es A.J.H. 1961. Hypomagnesaemia in milking cows: intake and utilization of magnesium from herbage by lactating cows. Neth. J. Agric. Sci. 9(2):134-149. <https://dx.doi.org/10.18174/ njas.v9i2.17628>

Kumssa D.B., Penrose B., Bone P.A., Lovatt J.A., Broadley M.R., Kendall N.R. \& Ander E.L. 2019. A reconnaissance survey of farmers' awareness of hypomagnesaemic tetany in UK cattle and sheep farms. Plos One 14(10):e0223868. <https://dx.doi.org/10.1371/journal.pone.0223868> $<$ PMid:31603922>

Larvor P. 1976. 28Mg kinetics in ewes fed normal or tetany prone grass Cornell Vet. 66(3):413-429. <PMid:954445>

Lee S.T., Cook D., Riet-Correa F., Pfister J.A., Anderson W.R., Lima F.G. \& Gardner D.R. 2012. Detection of monofluoroacetate in Palicourea and Amorimia species. Toxicon 60(5):791-796. <https://dx.doi.org/10.1016/j. toxicon.2012.05.029><PMid:22699106>

Lima E.F., Medeiros R.M.T., Cook D., Lee S.T., Kaehler M., Santos-Barbosa J.M. \& Riet-Correa F. 2016. Studies in regard to the classification and putative toxicity of Fridericia japurensis (Arrabidaea japurensis) in Brazil. Toxicon 115:22-27. <https://dx.doi.org/10.1016/j.toxicon.2016.03.001> $<$ PMid:26945838>

Macdonald K.A., Penno J.W., Lancaster J.A.S., Bryant A.M., Kidd J.M. \& Roche J.R. 2017. Production and economic responses to intensification of pasture-based dairy production systems. J. Dairy Sci. 100(8):6602-6619. <https://dx.doi.org/10.3168/jds.2016-12497><PMid:28601460>

Martens H. \& Blume I. 1986. Effect of intraruminal sodium and potassium concentrations and of the transmural potential difference on magnesium absorption from the temporarily isolated rumen of sheep. Q. J. Exp. Physiol. 71(3):409-415.<https://dx.doi.org/10.1113/expphysiol.1986.sp002999> $<$ PMid:3763804>

Martens H. \& Schweigel M. 2000. Pathophysiology of grass tetany and other hypomagnesemias: implications for clinical management. Vet. Clin. N. Am., Food Anim. Pract. 16(2):339-368. <https://dx.doi.org/10.1016/s07490720(15)30109-2><PMid:11022344>
Martens H., Leonhard-Marek S., Röntgen M. \& Stumpff F. 2018. Magnesium homeostasis in cattle: absorption and excretion. Nutr. Res. Rev. 31(1):1-17. <https://dx.doi.org/10.1017/S0954422417000257><PMid:29318981>

Martín-Tereso J. \& Martens H. 2014. Calcium and magnesium physiology and nutrition in relation to the prevention of milk fever and tetany (Dietary management of macrominerals in preventing disease). Vet. Clin. N. Am., Food Anim. Pract. 30(3):643-670. <https://dx.doi.org/10.1016/j. cvfa.2014.07.007><PMid:25245611>

Matto C., Gianneechini E. \& Rivero R. 2009. Principales características epidemiológicas de los focos de carbunco bacteridiano diagnosticados por el laboratorio regional noroeste "Miguel C. Rubino" en el período 19982009. XXVII Jornadas Uruguyas de Buiatría, Paysandú, Uruguay, p.189-191.

Mayland H.F. \& Grunes D.L. 1979. Soil-climate-plant relationships in the etiology of grass tetany, p.123-175. In: Grunes D.L. (Ed.), Grass Tetany. ASA Special Publication, The American Society of Agronomy, Crop Science Society of America and Soil Science Society of America, Madison, Wisconsin.

Mayland H.F. \& Wilkinson S.R. 1989. Soil factors affecting magnesium availability in plant-animal systems: a review. J. Anim. Sci. 67(12):34373444. <https://dx.doi.org/10.2527/jas1989.67123437x>

McCoy M.A. 2004. Hypomagnesemia and new data on vitreous humor magnesium concentration as a post-mortem marker in ruminants. Magnes. Res. 17(2):137-145. <PMid:15319147>

McCoy M.A., Hutchinson T., Davison G., Fitzpatrick D.A., Rice D.A. \& Kennedy D.G. 2001. Postmortem biochemical markers of experimentally induced hypomagnesaemic tetany in cattle. Vet. Rec. 148(9):268-273. <https://dx.doi.org/10.1136/vr.148.9.268><PMid:11292087>

McKenzie R. 1999. Precalving hypomagnesaemia in beef cattle post drought. Vet. Cont. Educ., Massey University 1999:145-148.

Metson A.J. 1974. I. Some factors governing the availability of soil magnesium: a review. N. Z. J. Exp. Agric. 2(3):277-319. <https://dx.doi.org/10.1080/ 03015521.1974.10427689>

Metson A.J., Saunders W.M.H., Collie T.W. \& Graham V.W. 1966. Chemical composition of pastures in relation to grass tetany in beef breeding cows. N. Z. J. Agric. Res. 9(2):410-436. <https://dx.doi.org/10.1080/0028823 3.1966.10420793>

Moraes J., Rivero R. \& Pereira D. 1993. Meteorismo espumoso, p.170-178. In: Riet-Correa F., Méndez M.C. \& Schild A.L. (Eds), Intoxicações por Plantas e Micotoxicoses em Animais Domésticos. Editorial Hemisferio Sur, Montevideo.

Moseley G. \& Baker D.H. 1991. The efficacy of a high magnesium grass cultivar in controlling hypomagnesaemia in grazing animals. Grass Forage Sci. 46(4):375-380. <https://dx.doi.org/10.1111/j.1365-2494.1991.tb02397.x>

Navarro M.A., Dutra F., Briano C., Romero A., Persiani M., Freedman J.C., E. Morrell E., Beingesser J. \& Uzal F.A. 2017. Pathology of naturally occurring bacillary hemoglobinuria in cattle. Vet. Pathol. 54(3):457-466. <https://dx.doi.org/10.1177/0300985816688945><PMid:28438111>

NRBC 2000. Nutrient Requirements of Beef Cattle. 7th ed. National Academy Press, Washington, p.129.

Odette 0. 2005. Grass tetany in a herd of beef cows. Can. Vet. J. 46(8):732-734. <PMid:16187719>

Ohno T., Grunes D.L. \& Sanchirico C.A. 1985. Nitrogen and potassium fertilization and environmental factors affecting the grass tetany hazard of wheat forage. Plant Soil 86(2):173-184. <https://dx.doi.org/10.1007/ BF02182892>

O'kelley R.E. \& Fontenot J.P. 1969. Effects of feeding different magnesium levels to drylot-fed lactating beef cows. J. Anim. Sci. 29(6):959-966. <https://dx.doi.org/10.2527/jas1969.296959x><PMid:5392902>

Pechin G.H., Cseh S. \& Keeny 0. 2011. Hipomagnesemia en vacas de cría en un campo de la zona del cardenal. Cienc. Vet., General Pico, 13(1):70-75. 
Pehrsson P.R., Patterson K.K. \& Perry C. 2008. The mineral content of U.S. drinking and municipal water. 32nd National Nutrient Databank Conference, Ottawa, Canadá. (Abstract).

Rayssiguier Y. 1977. Hypomagnesemia resulting from adrenaline infusion in ewes: its relation to lipolysis. Horm. Metab. Res. 9(4):309-314. <https://dx.doi.org/10.1055/s-0028-1093519><PMid:892696>

Riet-Correa F., Medeiros R.M.T., Pfister J., Schild A.L. \& Dantas A.F.M. 2009. Poisonings by Plants, Mycotoxins and Related Substances in Brazilian Livestock. Editora Pallotti, Santa Maria, p.15-22, 109-114.

Riet-Correa F., Schild A.L. \& Méndez M.C. 1990. Cetose em vacas de corte gestação. Pesq. Vet. Bras. 10(1/2):43-45.

Risso D.F. \& Berretta E.J. 2001. Tecnologías Forrajeras para Sistemas Ganaderos de Uruguay. Editorial Hemisferio Sur, Montevideo, p.18-146.

Rivero R., Quintana S., Féola R. \& Haedo F. 1989. Principales enfermedades diagnosticadas en el área de influencia del Laboratorio de Diagnóstico Regional Noroeste del CI.VET. "Miguel C. Rubino”. XVII Jornadas Uruguayas de Buiatría, Paysandú, Uruguay, p.75-76, 89-100, 108-109.

Rivero R., Riet-Correa F. \& Dutra F. 2000. Toxic plants and mycotoxins affecting cattle in sheep in Uruguay. XXI Congreso Mundial de Buiatría, XXVIII Jornadas Uruguayas de Buiatría, Punta del Este, Uruguay, p.1161, 1170. (Abstract).

Rodríguez A. \& Jacobo E. 2012. Manejo de pastizales naturales para una ganadería sustentable en la pampa deprimida: buenas prácticas para una ganadería sustentable de pastizal: kit de extensión para las pampas y campos. Fundación Vida Silvestre Argentina, Aves Argentinas (AOP), Argentina, p.13-15, 23-60, 85-87.

Rodríguez A.M., Schild C.O., Cantón G.J., Riet-Correa F., Armendano J.I., Caffarena R.D., Brambilla E.C., García J.A., Morrell E.L., Poppenga R. \& Giannitti F. 2018. White muscle disease in three selenium deficient beef and dairy calves in Argentina and Uruguay. Ciência Rural 48(5):e20170733. <http://dx.doi. org/10.1590/0103-8478cr20170733>
Saravia A., César D., Montes E., Taranto V. \& Pereira M. 2011. Manejo del Rodeo de Cría sobre Campo Natural. Programa Ganadero, Instituto Plan Agropecuario, Ministerio de Ganadería, Agricultura y Pesca Montevideo, p.8-22.

Urdaz J.H., Santos J.E., Jardon P. \& Overton M.W. 2003. Importance of appropriate amounts of magnesium in rations for dairy cows. J. Am. Vet. Med. Assoc. 222(11):1518-1523.<https://dx.doi.org/10.2460/javma.2003.222.1518>

Vasconcelos J.S., Riet-Correa F., Dantas A.F., Medeiros R.M.T. \& Dantas A.J.A. 2008. Mortes súbitas em bovinos causadas por Palicourea aeneofusca (Rubiaceae) e Mascagnia rigida (Malpighiaceae) na Zona da Mata Paraibana. Pesq. Vet. Bras. 28(10):457-460. <https://dx.doi.org/10.1590/S0100736X2008001000003>

Watson E.N., David G.P. \& Cook A.J.C. 2008. Review of diagnostic laboratory submissions of adult cattle 'found dead' in England and Wales in 2004. Vet. Rec. 163(18):531-535. <https://dx.doi.org/10.1136/vr.163.18.531> <PMid:18978365>

Welte E. \& Werner W. 1963. Potassium-magnesium antagonism in soils and crops. J. Sci. Food Agric. 14(3):186-187. <https://dx.doi.org/10.1002/ jsfa.2740140309>

Wilcox G.E. \& Hoff J.E. 1974. Grass tetany: an hypothesis concerning its relationship with ammonium nutrition of spring grasses. J. Dairy Sci. 57(9):1085-1089. <https://dx.doi.org/10.3168/jds.S0022-0302(74)85013-7> <PMid:4413598>

Wilkinson S.R., Stuedemann J.A., Grunes D.L. \& Devine O.J. 1987. Relation of soil and plant magnesium to nutrition of animals and man. Magnesium 6(2):74-90. <PMid:3573819>

Wittwer F., Contreras P.A., Silva N. \& Böhmwald H. 1997. Efecto de la suplementación con magnesio en alimento y agua sobre el control de tetania hipomagnesémica en rebaños Hereford. Arch. Med. Vet. 29(1):25-33. <https://dx.doi.org/10.4067/S0301-732X1997000100003> 